\title{
Hour Times Femtogram Per Milliliter Per Milligram Per Gram Per Day
}

National Cancer Institute

\section{Source}

National Cancer Institute. Hour Times Femtogram Per Milliliter Per Milligram Per Gram

Per Day. NCl Thesaurus. Code C117917.

Hour times femtogram per milliliter, divided by milligram per gram per day. 